condition of the Society. The address of the president, Mr. T. Southwell, is on the Extinction of Native Races. Among other papers of interest are: "Notes on Collecting Lepidoptera in Norfolk, 1878," by Mr. F. D. Wheeler; "Discovery of Remains of Emys lutaria in the Mundesley River-bed," by Mr. H. B. Woodward; The Bird-Life and the Geology of the Shiant Isles, by Mr. Harvie-Brown and Prof. IIeddle respectively; Notes on Hawking in Norfolk, by Prof. Newton and Mr. J. E. Harting; Ornithological Notes and Meteorological Observations.

The Proceedings of the Liverpool Naturalists Field Club for 1879-80 contains notes of the excursions and meetings of the Society. The only papers given are by the president, the Rev. H. H. Higgins, one being "Biographical Sketches in Zoology, from its Origin to its Union with Botany in the Science of Biology."

THE additions to the Zoological Society's Gardens during the past week include a Macaque Monkey (Macacus cynomolgus) from India, presented by Mr. J. Anson; a Side-Striped Jackal (Canis lateralis) from East Africa, presented by Commander Owen, R.M.S. Anglian; aCommon Ocelot (Felis pardalis) from Mexico, presented by Mr. A. L. Schütte; two Common Peafowls (Pavo cristata) from India, presented by Mrs. Joseph Hoare ; four Globose Curassows (Crax globicera), a Little Guan (Ortalida motmot) from British Honduras, presented by Mr. F. P. Barlee, C.M.G.; ten Amaduvade Finches (Estrelda aman. dava) from India, presented by Mr. J. W. Wilson; a Mississippi Alligator (Alligator mississippiensis) from North America, presented by Mr. T. L. M. Rose ; two Horrid Rattlesnakes (Crolalus horridus) from Nicaragua, presented by Messrs. Holt, Lord, and Co.; an Anaconda (Eunectes murinus) from South America, presented by Mr. G. H. Hawtayne; a Bonnet Monkey (Macacus radiatus) from India, an Arctic Fox (Canis lagopus) from the Arctic regions; a Nilotic Crocodile (Crocodilus vulgaris) from Africa, deposited; a Nylghaie (Boselaphus pictus) from India, a Collared Peccary (Dicotyles tajaçu) from South America, two Common Otters (Lutra vulgaris, $j v$.), British ; a Ground Hornbill (Bucorvus abyssinicus), an Elate Hornbill (Buceros elatus) from West Africa, a Virginian Eagle Owl (Bubo virginianus) from North America, a White-necked Crow (Corvus scapulatus) from Africa, purchased; a Collared Fruit Bat (Cynonycteris collaris), born in the Gardens.

\section{ON CURRENTS PRODUCED BY FRICTION BETWEEN CONDUCTING SUBSTANCES, AND ON A NEW FORM OF TELEPHONE RECEIVER ${ }^{1}$}

IN a communication to the Royal Society of Edinburgh of date January 6, 1879 , I showed that "electric currents were produced by the mere friction between conducting substances." The existence of these currents can be easily demonstrated either by a telephone or a Thomson's galvanometer. I have since found that these currents are, for all-pairs of metals which I have yet tried, in the same direction as the thermo-electric current got by heating the junction of the same two metals. They are also, approximately at least, stronger in proportion as the metals rubbed are far apart on the thermo-electric scale-the strongest current, as far as I have yet observed, being got by rubbing antimony and bismuth together. These observations clearly point to a thermo electric origin for the currents; but it is possible that they may be due partly to the currents suggested by Sir William Thomson as the cause of friction, and partly, also, to contact force between films of air or oxide adhering to the surfaces of the metals.

Having ascertained that these friction-currents are of some strength and fairly constant, I proceeded to make several kinds of machine for producing currents on this principle. One of them consists of a cylinder of antimony, which can be rotated rapidly, while a plate of bismuth is pressed hard against it by a

${ }^{x}$ Abstract of a paper read befure the Royal Society of Edinburgh by James Blyth, M.A., F.R.S.E., on May 3, 1880 . stiff spring. When this machine is included in the same circuit with a microphone and a Bell telephone, the current got from it is quite sufficient to serve for the transmission of musical sounds and also loud speaking. The transmitter, which I have found most serviceable in my experiments, is made by screwing two small cubes of gas-carbon to a violin, and placing between them a long stick of carbon pointed at both ends, the points being made to rest in conical holes in the carbon cubes. The looseness of the contact is regulated by a paper spring. This forms an excellent and handy trasmitter for all kinds of musical sounds, and also serves very well for transmitting speech.

Seeing that friction between metals clearly produces a current, it seemed natural to inquire if the converse held good, that is, if a current from a battery sent across the junction of two metals affected the friction of the one upon the other. I have tested for this in a variety of ways, and the results obtained leave me in doubt whether to attribute them to variations in the friction, or to actual sticking produced by fusion of the points of contact through which the current passes. The most noticeable effect is produced when one of the rubbing bodies is a mere point, and the other a smooth surface of metal. This led me to make a modification of the loud-speaking telephone of Mr. Edison, in order to get audible indications of changes of friction produced by the passing of a variable current. It consists of a cylinder of bismuth accurately turned and revolving on centres. The rubbing-point is made of a sewing-needle with its point bent at right angles, and its other end attached to the centre of the mica disk of a phonograph mouthpiece. It is evident that this is only a loose contact, which can be perpetually changed. When this apparatus is included in the circuit with the violinmicrophone and three or four Bunsen cells, the violin sounds, as was to be expected, are heard proceeding from the loosecontact, even when the cylinder is not rotated. They are in. creased, however, in a remarkable degree by rotating the cylinder slowly, so much so that a tune played on the violin can, with proper care, be distinctly heard all over an ordinary room.

With regard to the explanation of this effect, it is evident, that electrolysis can in no sense come into play, as is supposed to be the case in Edison's instrument. I am inclined to look for the explanation rather in the direction of the Trevelyan rocker, although the circumstances are considerably different in the two cases. In the rocker we have the heat passing from a mass of hot metal through two points of support to a cold block, whereas, in the other case, the heat is only intense at the points of contact, the rest of the metals being comparatively unaffected. The variations in the current produced by the transmitting microphone must cause corresponding variations in the heat at the point of contact of the needle with the cylinder, and this again produces a mechanical movement of the pressing point, as well as of the air surrounding it, sufficient to give forth soundwaves. If such be the case the effect should be different for different metals, those answering best which have the lowest thermal conductivity and also the lowest specific heat. That this is really so is shown by substituting cylinders of other metals for the bismuth, all other things remaining the same. In this way I have compared lead, tin, iron, copper, carbon, and find that they all give forth the simple loose contact-sound when the cylinder is stationary, but that it is only with bismuth that there is any very great intensification of the sound when the cylinder is rotated. Now, by consulting the appropriate tables I find that bismuth is a fraction lower than any other common metal in specific heat, while it is much below them all in thermal conductivity. This seems to bear out my explanation to a certain extent.

\section{UNIVERSITY AND EDUCATIONAL INTELLIGENCE}

CAMBRIDGE.-The subject for the Sedgwick Prize essay, 1883 , is "The Classification of the Cambrian and Silurian Rocks." The prize is open to all graduates of the University of Cambridge who have resided sixty days during the twelve months preceding October I, 1882. The essays must be sent in to the Registrary on or before October I, I882.

\section{SCIENTIFIC SERIALS}

Proceedings of the Academy of Natural Sciences of Philadelphia. Part I, January to April,-Thomas Meehan, on disarticulating branches in Ampelopsis (the annual growth is dis- 